\title{
Trends of U.S.-China Trade Disputes and Beijing's Policy Options
}

\author{
Sun Tianhao and \\ Wang Yan
}

\begin{abstract}
Although the intensified trade disputes between China and the United States accord with the basic theory of international political economy, they are unlikely to escalate into a trade war in a world characterized by the inexorable forces of globalization. What lies behind the Trump administration's aggressive trade policy toward China is a bipartisan consensus on the growing need to reduce U.S. trade deficits, rein in China's non-market economic forces, slow down China's technological innovation and industrial upgrading, as well as to create political pressure on China to
\end{abstract}

Sun Tianhao is a post-doctoral fellow at the Institute of International Economics, School of Economics, Nankai University, and a visiting scholar at the University of North Carolina at Chapel Hill. His mailing address is: Tianjin Postdoctoral Apartment, 285 Baidi Road, Nankai District, Tianjin 300192, China. He can also be reached at nc27514sun712@gmail. com. Wang Yan is a Ph.D. candidate at both the Dongbei University of Finance and Economics and the University of North Carolina at Chapel Hill.

This article is sponsored by the Postgraduate Scholarship Program for Building High-level Universities endorsed by the China Scholarship Council.

(c) 2018 World Century Publishing Corporation and Shanghai Institutes for International Studies China Quarterly of International Strategic Studies, Vol. 4, No. 4, 543-557

DOI: $10.1142 / S 2377740018500276$

This is an Open Access article, copyright owned by the SIIS and WCPC. The article is distributed under the Creative Commons Attribution 4.0 (CC BY-NC) Licence. Further distribution of this work is permitted, provided the original work is properly cited and for non-commercial purposes. 
rectify its allegedly malign practices in global economic arenas. Motivation analysis suggests that the ongoing trade disputes are a product of the United States trying to coerce a potential challenger into adjusting its industrial development strategy and to prevent a determined rising power from pursuing national revival on its own terms. Lessons drawn from the trade conflicts between Japan and the United States in the 1980s suggest that Beijing may encounter even more trade frictions with Washington in the next few years. China must stand its ground under growing political and economic pressure, define trade disputes in strictly economic terms, and deal flexibly with their impacts. The lasting trade tensions between China and the United States has also exposed Beijing's strategic shortcomings and forced China to enhance its innovation capacity while fostering independent intellectual property, so as to consolidate its comprehensive national power.

Keywords: Sino-U.S. trade dispute; international political economy; "Thucydides Trap; " Made in China 2025.

Economic tension between China and the United States has been rising since March 2018 when the Trump administration announced that it would impose additional tariffs on $\$ 50$ billion worth of Chinese exports, spurring wide speculations on both sides of the Pacific that a full-scale trade war between the world's two largest economies is imminent. This article attempts to answer three major questions from the perspective of international political economy: First, what is the nature of the Sino-U.S. trade disputes? Second, how likely will Beijing and Washington fall into the socalled "Thucydides Trap" in economy? And third, what policy options are available for China to tackle mounting U.S. trade restrictions?

\section{Escalating Sino-U.S. Trade Tensions}

The current round of bilateral trade frictions began in March 2018 and escalated as the United States Trade Representative (USTR) initiated a Section 301 investigation. According to the annual Special 301 Report, China's allegedly unfair trade practices have inflicted an economic loss of $\$ 50$ billion on the United States. Although it claims that "China uses foreign ownership restrictions, such as joint venture requirements and foreign 
equity limitations, and various administrative review and licensing processes, to require or pressure technology transfer from U.S. companies," ${ }^{1}$ the report has produced no specific case in support of the charges. In fact, not a single provision that forces technology transfer to Chinese partners in joint ventures can be found in any Chinese law or regulation regarding foreign investment. Thus, many believe that the groundless charges are the Trump administration's fabrications with the intention to contain China's rise by curbing its industrial development. ${ }^{2}$

According to statistics released by the Chinese Ministry of Commerce, China's total volume of trade in goods in 2017 exceeded $\$ 4.1$ trillion, among which 580 billion was with the United States, accounting for 14.1 percent of the total. The $\$ 50$ billion hit by the U.S. added tariffs only accounts for 1.2 percent of China's trade in goods and less than 9 percent of trade with America. There has not been a uniform quantifiable measure of what constitutes a trade war, but judging from the above numbers, it is an exaggeration to use the phrase "trade war" to describe the current round of trade frictions between China and the United States.

\section{China and the U.S.}

are not in a trade

war, but frictions in

high-tech

development will

continue.

As the U.S. tariff lists reveal, the chief targets of U.S. restrictive measures are Chinese high-tech products: Chinese sectors subject to the U.S. tariffs include industries such as aerospace, information and communication technology, robotics, and machinery; the categories hit hardest by U.S. tariffs are mechanical apparatus and components, electric motor, electric products, audio-visual equipment and components/accessories, as well as optical, photographic and medical devices and components/accessories, which altogether accounted for about 53 percent of China's total exports to America in 2017.

${ }^{1}$ Office of the United States Trade Representative, 2018 Section 301 Report (Washington, D.C.: Office of the United States Trade Representative, 2018).

${ }^{2}$ For example, see Cankaoxiaoxi, “Ximei: Zhongguo ganchao meiguo xingshi minglang Mei fadong maoyizhan zhizai ezhi zhongguo [Western Media: When China Is Sure to Catch up, the U.S. Launches Trade War to Contain China]," August 1, 2018, http://www.cankaoxiaoxi. com/finance/20180801/2302901.shtml. 
Table 1. Sino-U.S. Trade Disputes in March-April 2018.

\begin{tabular}{|c|c|}
\hline 18 & $\begin{array}{l}\text { The Trump administration announced a } 25 \text { percent tariff on imported steel and } \\
\text { a } 10 \text { percent tariff on aluminum (Canada and Mexico were exempted as } \\
\text { NAFTA members). }\end{array}$ \\
\hline Iarch 22 & $\begin{array}{l}\text { Trump signed a memorandum requesting the USTR to impose tariffs on } \$ 60 \\
\text { billion worth of imported goods from China according to Section } 301 \text { of the } \\
\text { U.S.' Trade Act of } 1974 \text {. }\end{array}$ \\
\hline 23 & $\begin{array}{l}\text { Chinese Ministry of Commerce announced that it would impose tariffs on } \\
\text { more than } 100 \text { categories (including fruits and seamless steel pipes) of } \$ 3 \\
\text { billion worth of goods from the United States to balance for the economic } \\
\text { loss caused by U.S. tariffs on Chinese steel and aluminum. }\end{array}$ \\
\hline pril 2 & $\begin{array}{l}\text { China suspended concessions on } 128 \text { tax products across } 7 \text { categories imported } \\
\text { from the United States and imposed additional tariffs on top of current } \\
\text { rates. }\end{array}$ \\
\hline pri & $\begin{array}{l}\text { The USTR released a List of Proposed Chinese-Made Goods for Tariffs in- } \\
\text { volving approximately } \$ 50 \text { billion of Chinese imports with a proposed tax } \\
\text { rate of } 25 \text { percent, covering } 1,333 \text { separate tariff numbers. China reacted by } \\
\text { imposing a } 25 \text { percent tariff on } 106 \text { tax products across } 14 \text { categories from } \\
\text { America including soybeans and automobiles. At the same time, China filed } \\
\text { a request for consultation with the United States under the WTO dispute } \\
\text { settlement mechanism, starting officially the dispute settlement procedure. }\end{array}$ \\
\hline Apri & $\begin{array}{l}\text { Trump requested the USTR to impose additional tariffs on } \$ 100 \text { billion worth of } \\
\text { goods imported from China. Japan and the European Union joined the } \\
\text { United States in a request for consultation with China at the WTO to ad- } \\
\text { dress China's discriminatory technology licensing requirements. }\end{array}$ \\
\hline pril 16 & $\begin{array}{l}\text { The U.S. Department of Commerce banned U.S. companies from selling crucial } \\
\text { hardware and software products to China's ZTE corporation for seven } \\
\text { years. China immediately reacted by launching provisional anti-dumping } \\
\text { measures against grain sorghum originating in America. }\end{array}$ \\
\hline
\end{tabular}

Source: Compiled by the authors. ${ }^{3}$

Remaining at the mid- and low-ends in global value chains, China's manufacturing industry produces mostly low-tech products. As China lacks the capacity to produce high-tech goods, those sectors reliant on American technology have become the chief victims of the latest round of trade tensions. Chinese sectors that enjoy longstanding comparative advantages like textiles and furniture are not targets of the recent Section 301 investigation. China's exports are complementary to the United States'

\footnotetext{
${ }^{3}$ For a complete timeline of the Trump administration's trade measures toward major economies, see Chad P. Bown and Melina Kolb, Trump's Trade War Timeline: an Up-to-Date Guide (Washington, D.C.: Peterson Institute for International Economics, 2018).
} 
capital-intensive industries. Since America cannot find viable alternatives, China's labor-intensive sectors are also exempted from the U.S. restrictive measures. Primary products, whose import and export is the natural result of international division of labor, are therefore not the prime victims of the trade disputes. The bone of contention is China's manufacturing industry, especially those sectors listed in China's Made in China 2025 plan.

The Made in China 2025 plan was released by the Chinese government in May 2015 in response to a new round of global technological and industrial revolution. It is the first 10-year action plan designed to transform China from a manufacturing giant into a world manufacturing power. Key sectors mentioned in the plan include new information technology, numerical control tools and robotics, aerospace equipment, energy saving and new energy vehicles, new materials, biological medicine and medical devices, etc. In particular, China strives to be the world's pacemaker in sectors like high-speed rail and heavy equipment. ${ }^{4}$ Moreover, the gap between China and the United States in GDP is also closing, as four decades of reform and opening-up have made China the world's second largest economy and the largest industrial country. In short, China's rapid rise in science and technology, industry and economy have exerted increasing pressure on the United States, which is reflected in its Special 301 Report.

What makes the current round of trade conflicts different from the previous ones is that China's advanced industries, including robotics, biotechnology, and artificial intelligence, are the prime targets. As its science and technology sectors expand and labor costs grow, China's comparative advantages in labor-intensive industries have diminished and its factor endowments have begun to shift to capital- and technology-intensive sectors. The pattern of bilateral trade between China and the United States may, in the not too distant future, gravitate to intra-industry trade - an inevitable departure from the current inter-industry trade. That means there will be increasingly intense competition between Chinese and American products in the same industries.

\footnotetext{
${ }^{4}$ For a comprehensive review of the plan, see Sylvia Liu, "Innovation Design: Made in China 2025," Research Gate, January 2016, https://www.researchgate.net/publication/ 323869484_Innovation_DesignMade_in_China_2025.
} 


\section{What Lies Behind Trump's Aggressive Trade Policy?}

Besides President Trump's calculations for the U.S. midterm election and a potential reelection for the second term, the chief motivation behind his restrictive measures against China is a growing bipartisan consensus on the urgent need to reduce U.S. trade imbalances, rein in China's nonmarket forces, slow down China's technological innovation and economic expansion, and ultimately prevent China's rise as America's peer competitor.

Before the midterm election held in November 2018, President Trump's rhetoric and actions against China were mainly aimed at rallying support for the Republicans, for he had been making every effort to fulfill his campaign promises such as manufacturing reinvigoration, job creation, and restoration of balance of payments, and the GOP's continued majorities in both the Senate and the House of Representatives would largely depend on whether his economic policy can yield concrete results. In this aspect, the Trump administration's protectionist measures were part of the Republicans' political campaign to win over the hearts of American voters. For example, the implementation of tariffs on steel and aluminum was intended to please workers in the two industries in Pennsylvania, which produces nearly a quarter of America's steel products.

Now that the midterm election is over, President Trump has shifted his focus to bringing the bilateral trade into a new balance and constraining China's non-market forces. According to official statistics, the United States ran a record-high trade deficit of $\$ 375$ billion with China in 2017, nearly half of the U.S. global trade deficits. ${ }^{5}$ In pursuit of the so-called "free and fair trade," President Trump has resorted to increased tariffs to reduce U.S. trade deficits. In the 2018 Trade Policy Agenda and 2017 Annual Report, the

\section{Trump's aggressive trade measures are aimed to stall China's rapid economic rise.}

\footnotetext{
${ }^{5}$ Kimberly Amadeo, “US Trade Deficit With China and Why It's So High,” The Balance, January 18, 2019, https://www.thebalance.com/u-s-china-trade-deficit-causes-effects-andsolutions-3306277.
} 
Trump administration vilified China as "a statist economic model with a large and growing government role" and resented China's "enormous capacity to distort markets worldwide." ${ }^{\prime 6}$ As a result, President Trump threatened to levy more tariffs on Chinese goods and put a stop to China's economic development model.

In the longer run, it is expected that the recent trade tensions will be exploited by the Trump administration to consolidate the U.S. technological superiority by curbing China's technological innovation and industrial upgrading. To many Americans, China's growing economic size itself poses a challenge to the U.S. economic supremacy and requires a reassessment of the U.S.' strategic posture toward its principal rival. As many see it, great power competition in the 21st century is first and foremost a technological competition. ${ }^{7}$ Arguably, what the United States attempts to achieve with the newly imposed tariffs on Chinese goods is to slow down - and, if possible, halt - China's pace on the path toward becoming a technology giant.

In addition to imposing tariffs, the Trump administration has raised many barriers to Chinese investment in America. For example, Washington has invoked the International Emergency Economic Powers $A c t^{8}$ to increase scrutiny of Chinese high-tech companies' investment in America with the aim of preventing the leak of trade secrets and potential theft of intellectual property. Clearly, the Trump administration's real endgame with China

${ }^{6}$ Office of the United States Trade Representative, 2018 Trade Policy Agenda and 2017 Annual Report (Washington, D.C.: Office of the United States Trade Representative, March 2018), p. 4.

${ }^{7}$ See, for example, Elsa Kania, “Great Power Competition and the AI Revolution: A Range of Risks to Military and Strategic Stability," Lawfare, September 19, 2017, https:// www.lawfareblog.com/great-power-competition-and-ai-revolution-range-risks-militaryand-strategic-stability. Similarly, top Chinese leaders continually underscore the importance for China to become a great power in science and technology. See “科技强国 (kējì qiángguó): Great Power in Science and Technology," China Daily, May 30, 2018, https://global.chinadaily.com.cn/a/201805/30/WS5b0dd7a0a31001b82571d05f.html.

${ }^{8}$ The Act is a federal law enacted in 1977 authorizing the U.S. President to regulate commerce after declaring a national emergency in response to any unusual and extraordinary threat originating outside the United States. Measures in this regard include restricting foreign investment, nullifying business contracts, and freezing assets. 
goes far beyond trade imbalances and theft of intellectual property; the protective tariffs and closer scrutiny of Chinese investment are part of America's coordinated and comprehensive strategy to impede China's technological innovation and industrial upgrading.

In sum, the Trump administration is resorting to protective tariffs for both political and economic reasons. Ultimately, the current round of trade disputes between Beijing and Washington may boil down to a geoeconomic and geopolitical competition between an economic hegemon trying to coerce a challenger into compliance and an emerging power standing firm on its development path.

\section{A "Thucydides Trap" in Economy?}

More than 2,400 years ago, Athenian historian Thucydides predicted that, within a given system of states, a rising power was bound to pose serious challenges to an established power in that system, which would have no other choice but to react forcibly; a war between them was thus inevitable. ${ }^{9}$ Viewed from this perspective, the so-called "Thucydides Trap" is ultimately a zero-sum game between a rising power and an established power. Today, however, direct, full-scale and lasting military confrontation between two nuclear-armed powers is almost unfathomable, for it may very possibly lead to mutual destruction. But that does not mean that an established power will not resort to other means short of war to rein in the rising power; and the economic instrument is usually the most effective in the former's foreign policy toolkit.

Although China has repeatedly articulated its adherence to peaceful development, Washington still views Beijing as its greatest geopolitical competitor. As Tsinghua professor Yan Xuetong put it, "China and America are like two Chinese chess players. It is only natural and reasonable for America to try to have the other's king in check. In a strategy board game, trying to capture the rival's king is not a matter of morality, it is a matter of rational or irrational tactics." ${ }^{10}$ Therefore, the strategic choice for America is

${ }^{9}$ Thucydides, History of the Peloponnesian War (London: Penguin, 1972).

${ }^{10}$ Interview with Professor Yan Xuetong on April 2, 2018, http://www.sohu.com/a/ 227446188_574698. 
between standing aside and watching China grow into a great power on par with America, and forestalling China's rise by all means available, including trade protectionism. For the time being, the Trump administration seems to have chosen the latter. But the force of globalization is unstoppable, and as China integrates more deeply into the global economic system, it is impossible for America to contain China's rise all by itself. What the United States can do at best is erect as many barriers as possible to slow down China's pace of economic growth and, in particular, high-tech industrial development.

Take the U.S.-Japan trade frictions in the 1980s as an example. Japan's postwar economic reconstruction with the help of American trade and investment had propelled it to become the second-largest economy in 1968, little more than two decades after its defeat in World War II. But Japan's economic trajectory during that period was burdened with serious trade conflicts with Washington. Especially after the two oil crises in the 1970s, trade tensions escalated as large Japanese automobile manufacturers such as Toyota and Honda overwhelmed the American market with their fuelefficient products. On the whole, Japanese exports to the United States expanded to 35.2 percent of its global exports from 1980 to 1984. The Reagan administration's policy of high interest rates of the U.S. dollar further increased U.S. trade deficits with Japan. In this context, Washington decided to be tough toward its most valuable Asian ally which had turned out to be its biggest economic challenger.

Through a series of unilateral sanctions - applying "super 301 provisions" to certain categories of Japanese goods, for example - and bilateral negotiation, Washington forced Tokyo to give American high-tech and agricultural products access to the Japanese markets in 1988; the Japanese Yen also appreciated significantly against the U.S. dollar in accordance with the Plaza Accord. ${ }^{11}$ Moreover, Washington exerted much political pressure on Tokyo to launch institutional reforms to the economy in favor of U.S. interests. As a result, Japanese industrial competitiveness began to diminish in the early 1990s, and its economy has since been

${ }^{11}$ The Plaza Accord is an agreement signed at the Plaza Hotel in New York City on September 22, 1985, among the governments of France, West Germany, Japan, the United States, and the United Kingdom, to depreciate the U.S. dollar in relation to the Japanese yen and German Deutsche Mark by intervening in currency markets. 
sluggish. The trade war between Japan and the United States was a critical turning point for Japan as it seriously undermined Tokyo's economic momentum and paved the way for the subsequent housing bubbles.

Compared with Japan, China is an even bigger strategic challenger to the United States, since its economic size, technological sophistication and global influence have outpaced Japan during the peak of its economic growth. Thus, it is natural for the United States to take If not handled well, U.S.-China trade disputes may cause lasting decline of Chinese economy. much more stringent, diversified, and restrictive measures against China.

A comparison between the ZTE incident in 2018 and the ToshibaKongsberg incident in the 1980s may shed some light on the U.S. policies toward major economic competitors. The Toshiba-Kongsberg incident involved Toshiba Machine Company of Japan and Kongsberg Group of Norway, both found to have secretly supplied milling machines and accompanying numerical control equipment to the Soviet Union in violation of the regulations of the Coordinating Committee for Multilateral Export Controls. The U.S. government believed that the two companies' illicit transfer of advanced milling machinery to the Soviet Union had enabled Moscow to develop much quieter submarine propellers, narrowing the U.S. technological advantages over its arch rival during the Cold War. The incident provided the rationale for the U.S. government to ban the products of Toshiba Machinery Company from entering the American market. The incident also gave Washington a rare opportunity to force Japan to relax its restrictions on the export of high-technology products. ${ }^{12}$ Likewise, the ZTE incident involved a Chinese telecommunications giant illicitly selling banned equipment - using American parts - to Iran. As a result, the company was hit with a seven-year ban which would stop ZTE from using

${ }^{12}$ Wende A. Wrubel, “The Toshiba-Kongsberg Incident: Shortcomings of COCOM, and Recommendations for Increased Effectiveness of Export Controls to the East Bloc," American University Journal of International Law and Policy, Vol. 4, No. 24 (1989), pp. 241-273; and M. J. Heale, "Anatomy of a Scare: Yellow Peril Politics in America, 1980-1993," Journal of American Studies, Vol. 43, No. 1 (2009), pp. 19-47. 
American components. ${ }^{13}$ In the context of growing trade tensions between the United States and China, both the incident and its potential impact have been amplified. The Trump administration has exploited the incident to increase political pressure on the Chinese government to gain extra leverage in trade negotiations and to curb the rapid development of China's telecommunications industry. In both cases, the United States took similar restrictive trade measures to punish its competitors which had relied heavily on advanced U.S. technologies for their own industrial development.

Although trade benefits all to different extents, actors in global economic competition tend to be more concerned about their relative gains than absolute ones for understandable reasons. To them, triumph is not achieved without costs, but as long as one can inflict greater pains on its rival, it is a price worth paying. The Trump administration had anticipated China's countermeasures in response to the U.S. trade tariffs before initiating the 301 investigation, and went along with it by all means, because in the White House's calculation, in order to attain the strategic goal of maintaining U.S. technological superiority by curbing China's high-tech industry, some sacrifices have to be made. ${ }^{14}$

As it continues to grow in economic size, military prowess, and technological sophistication, China will only encounter more challenges and barriers posed by the reigning economic hegemon. As Tsinghua professor Sun Xuefeng put it, "China has encountered and must overcome a 'rising power's dilemma' in which an emerging great power is trying to turn its growing material strength into wider systematic influence while in the process making every effort to prevent the formation of a balancing coalition." ${ }^{15}$ Trade is the major arena at this stage while intensifying

${ }^{13}$ David Meyer, “China's ZTE Is Working Again in the U.S. Just as Lawmakers Push for Heavier Sanctions on the Telecom Giant," Fortune, July 4, 2018, http://fortune.com/2018/07/ 04/zte-us-authorization-trump/.

${ }^{14}$ Peter Skurkiss, “Trade Wars and China," American Thinker, December 27, 2018, https://www.americanthinker.com/articles/2018/12/trade_wars_and_china.html; and Panos Mourdoukoutas, "China Will Lose the Trade War With America, And That's Good for Its Citizens," August 5, 2018, https://www.forbes.com/sites/panosmourdoukoutas/2018/08/05/ china-will-lose-the-trade-war-with-america-and-thats-good-for-its-citizens/\#319fc0b73461.

${ }^{15}$ Sun Xuefeng, Dilemma of China's Rise: Theoretical Reflections and Strategic Options (Beijing: Social Sciences Academic Press, 2012), p. 186. 
U.S.-China rivalry in other fields will follow, for it is the inevitable result of a fast rising China resisting and pushing back against growing pressure exerted by a strategically anxious United States. Although direct and fullscale military confrontation between China and the United States is still unthinkable, a "Thucydides Trap" in the economic arena is already lurking ahead.

\section{China's Policy Options}

Any deliberation over China's policy options in response to the escalating trade tension and intensifying strategic competition between Beijing and Washington must, first and foremost, be based on the sober fact that there is little possibility of China overtaking the United States in comprehensive national power in the near future. In the next two decades, what China can possibly achieve at best is to approach the United States in economic competitiveness and military power parity. Given that, two options seem most practical and effective for managing the trade tensions with the United States for the time being: (1) avoid linking trade disputes with other contentious issues between both countries; and (2) remain resolute in fighting back when necessary.

Like in other wars, there is no absolute winner in a trade war. The Trump administration will have to return to the negotiating table when it finds that the price of a trade war with another economic giant is much more than the general public are ready to pay. In this sense, time is on China's side because both the White House and Congress may change hands in the next few years. A Democratic president or a liberal-controlled Congress may change course (although it is difficult to change the general trends of Sino-U.S. strategic competition).

Moreover, China's political system and decision-making process have enabled it to withstand prolonged trade disputes. Take agricultural produce as an example. As a countermeasure to the U.S. added tariffs, China has raised tariffs on nearly 90 percent of agricultural produce imported from the United States since July 2018. To compensate the American farmers who have suffered as a result of Sino-U.S. trade frictions, President Trump pledged $\$ 12$ billion in agricultural subsidies, but the sum is far from enough to offset the losses, and the United States can hardly find a substitute for China's huge consumer market any time soon. Based on such 
considerations, China imposed tariffs on targeted products from those swing states in America, in order to pressure the Trump administration to return to the negotiating table.

\section{Time is on China's}

side in its strategic

competition with

the U.S.

In the short term, it is widely predicted that the current round of trade disputes will end with mutual concessions and compromises. ${ }^{16}$ What is important for China is how to gain extra leverage in the negotiating process and make the end results beneficial to its own development and people's welfare.

The sticking point is how to address the long-running trade imbalances between China and the United States. One feasible option is for China to increase imports from America. Specifically, the import of parts, components, and strategic resources will promote the technological upgrading of China's manufacturing industry; the import of consumer goods will meet the demands of Chinese consumers; the import of productive services will upgrade the value chain of manufacturing. Apart from reducing trade imbalances, these measures also help improve the Chinese people's livelihoods and the environment. More importantly, Beijing should try its best to persuade Washington to relax export restrictions on high-tech products, one of the root causes of longstanding U.S. trade deficits with China. It is worth noting that for both Beijing and Washington, dispute settlement mechanisms and effective trade remedies in the WTO-centered multilateral trading system are the best institutional safeguards.

In the long run, China should follow a well-conceived and effectively implemented development strategy, especially a blueprint for strategic industrial development. To overcome the "rising power's dilemma," China has to push back against U.S. geopolitical and geoeconomic pressure on the one hand, and try to achieve win-win results on the other.

${ }^{16}$ See, for instance, Charles Wallace, “U.S.-China Trade Talks Resume with Optimism for a Deal," Forbes, January 7, 2019, https://www.forbes.com/sites/charleswallace1/2019/01/ 07/us-china-trade-talks-resume-with-optimism-for-a-deal/\#77f868a86554. Meanwhile, there remains much suspicion on what kind of deal will be reached between China and the United States. See Rick Noack, "How Trade Wars End and Why Trump's Will Be Different," The Washington Post, April 4, 2018, https://www.washingtonpost.com/news/ worldviews/wp/2018/04/04/how-trade-wars-end-and-why-trumps-will-be-different/? utm_term=.dc6756391cd7. 
After all, the rise of China depends on its own strenuous efforts on development. History of the past seven decades indicates that any attempt to block or contain China's development has been futile. What China seeks is a generally stable environment that is conducive to free trade. To counter the U.S. comprehensive efforts to curb the development of China's advanced and high-tech industries through restrictive trade measures, it is best for Beijing to keep pushing forward a structural reform. As the largest nation with a deep memory of the "centennial humiliation" imposed by colonial powers from the mid-19th century to the founding of the People's Republic in 1949, China will not bend to any outside pressure, ${ }^{17}$ but the ZTE incident has exposed the inadequacies of China's innovative capacities. China has to rely more on indigenous technological innovation if it wants a better position in future global industrial competition. As its economic output continues to expand, economic efficiency and competitiveness must also be improved. Historical evidence in the West has proven that an advanced economy must be grounded upon a strong manufacturing base. Therefore, fulfilling the Made in China 2025 plan at an early date should remain a top priority in China's development strategy, regardless of the current doubts and hostility from the United States and other developed countries.

Japan's experience in the 1980s offers a telling example of why China must focus on innovation-driven reforms rather than resorting to stimulus packages in the face of external economic and political pressure. Japan's "lost twenty years" began with the collapse of the asset price bubble and the Bank of Japan's sharp policy of raising inter-bank lending rates. All this happened under enormous U.S. economic and political pressure. Now, under similar circumstances, instead of stimulating the economy in pursuit of relatively high GDP growth rates, Beijing should take a long view and give priority to technological innovation and industrial upgrading so as to build a robust and sustainable real economic base.

In the meantime, Beijing should work with Washington to explore the possibility of establishing a stable and sustainable framework of arrangements to manage their trade relations. Coercive economic measures like

${ }^{17}$ On how China tends to attach a sense of humiliation to Western pressure, see Paul Heer, "Understanding the Challenge from China," Asan Forum, 3 April, 2018, http://www. theasanforum.org/understanding-the-challenge-from-china/. 
trade tariffs and tightened scrutiny are only short-term negotiating tactics. Healthy economic relations must operate under a set of mutually agreed norms and rules. A new, rules-based type of great power relationship between Beijing and Washington in economic issues will not only be beneficial to both countries, but also help stabilize an increasingly interdependent world.

As competition between China and the United States is inevitable, the focus should be on how the two giants can achieve benign competition to improve the technological progress of both countries while enhancing the well-being of mankind through the competing provision of international public goods. For one, China and the United States should observe the basic rules for bilateral competition, such as respect for each other's top leadership and path of development, sincerity in settling disputes through timely and candid talks, and trying their best to fulfill their promises and agreed terms. Only if both sides follow a set of mutually agreed rules, can benign competition be achieved. For another, China and the United States should continue expanding cooperation in other fields to offset the negative impact of trade and economic disputes - although history of the two world wars indicates that close economic interdependence cannot totally stop war from breaking out between two hostile rivals, when it is coupled with enhanced political, cultural and people-to-people exchange as well as the menacing scenario of mutual mass destruction, it can at least help both sides take a sober and pragmatic stance in their enduring competition and prevent a "de-coupling" of their economies. By expanding their common interests and consciously attempting to settle disputes through closer talks and mutual compromises, China and the United States can turn the current dynamics of trade disputes and economic competition into a new start of great power cooperation for continued peace and development of the world. 